\title{
2014
}

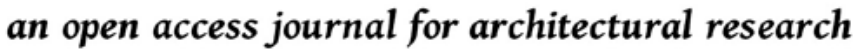

volume 11 | issue 1

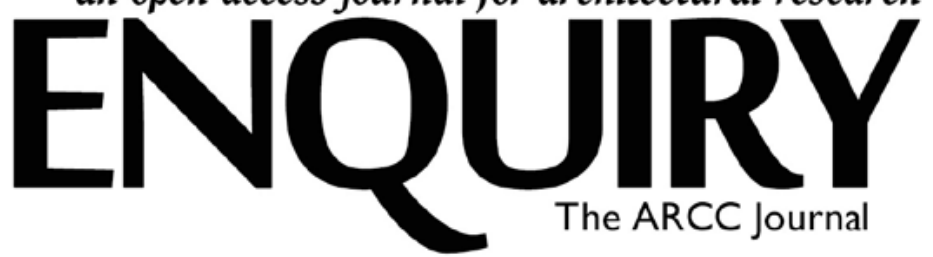

\section{THE COURTYARD INSIDE AND OUT: A BRIEF HISTORY OF AN ARCHITECTURAL AMBIGUITY}

\author{
Robert Nelson
}

\begin{abstract}
Though a mainstream building archetype for many centuries, courtyards have never been well defined in the history of language. Combining phenomenological and philological research methods, this article proposes a timeline in which courtyards grew with great architectonic presence as a vivacious stage for human interaction, but without a corresponding lexical stability to reflect their function and presence. The article reveals that the ambiguities of contemporary usage of the word 'courtyard' are not unprecedented; because in all epochs and across key European languages, the term is weak and ill-defined.
\end{abstract}

Courtyards have a unique charm which the article characterizes as social presence and which is explored through historical narratives. The article argues that the relevant history of language and narrative about courtyards not only helps us discover their enchanting spatiality but also helps us imagine an architectonic destiny for courtyards against the many factors that discourage their contemporary proliferation.

\section{INTRODUCTION AND METHOD}

In various epochs, courtyards belonged to common experience. They were not only a feature of grand estates with an inward sanctuary but were equally to be found at the heart of modest quarters from antiquity to the nineteenth century. Alas, the evidence of old buildings only testifies to the bald fact that courtyards must have belonged to common experience; we cannot so easily establish the meaning of these open spaces in the middle of buildings, either architecturally or historically.

\section{Permissions and copyright}

Authors retain copyright and grant the journal right of first publication with the work simultaneously licensed under a Creative Commons Attribution License that allows others to share the work with an acknowledgement of the work's authorship and initial publication in this journal (Attribution-ShareAlike).

Creative Commons Attribution 3.0 Unported (CC BY 3.0)

You are free to: Share - copy and redistribute the material in any medium or format. Adapt - remix, transform, and build upon the material for any purpose, even commercially. The licensor cannot revoke these freedoms as long as you follow the license terms.

Under the following terms: Attribution - You must give appropriate credit, provide a link to the license and indicate if changes were made. You may do so in any reasonable manner, but not in any way that suggests the licensor endorses you or your use.

No additional restrictions - You may not apply legal terms or technological measures that legally restrict others from doing anything the license permits.

How to cite:

Nelson, Robert. 2014. "The courtyard inside and out: a brief history of an architectural ambiguity." Enquiry 11 (1): 8-17.
What was the experience of courtyards and what do they have to say to us today?

Through examining the courtyard, this article proposes a method for handling broader questions of architectural experience. We can easily say what buildings contain but it is much harder to say what they feel like in anything but a subjective way, which may be insightful and even seductive but possibly eccentric and capricious, dependent upon a personal point of view, and hence tainted with arbitrariness. The subjectivity itself is undoubtedly valuable - and one can argue that nothing is felt unless apprehended in a feeling subject - but as an element in research, it requires other data by which it might be triangulated. In particular, the history of experience revealed by language provides a perspective from which an architectural institution like the courtyard can be seen in sharper relief.

In order to triangulate architectural subjectivity, this article brings together both the appearance of courtyards and the language by which we characterize them. It is an area of the built environment which is still surprisingly difficult to define; so the article proposes a method for identifying the phenomenon which is radical in the sense of seeking roots. In the same way that we may hope to identify a feeling or intuition by observation, so we may hope to find the roots of experience in the history of language. Accordingly, this paper seeks a match between the observational and the philological: it explores courtyards in their physical properties as a lived circumstance, but it also seeks to relate this phenomenological description to the philological evidence, most of which has never been examined before.

Thus, the article observes the internal courtyard not just as abstract layout but as a scheme of architectonic advantages with practical and moody consequences; and from these intuitions, it traces the history of the motif not just through the evidence of building archetypes but their lexical and literary records. We immediately encounter telling paradoxes. The literal centrality of courtyards to so many traditions of urban construction does not save them from confusion in the way that they are described. Even in earlier times, the motif proves quite weak in vocabularies, despite its remarkable social presence. 
This paradox encourages a further phenomenological conjecture about the 'void' at the core, the presence which is made of absence, somewhat like space itself but peculiarly dedicated, almost enshrined, as an architectural institution of the elements of light and air, a stage, a closely guarded platform, both shy and ostentatious, retiring and literally courtly, both protected and outgoing and a zone for gregarious behaviour, as we shall see. The courtyard enables a building to start again, as if the façade that fronts onto the street yields to another façade or quadruple façades that elaborate both the presence of the building and the entry to its interior. In this project of describing something through both the subjective history of form and the objective history of its linguistic tags, the method requires many folds, where the one data set provides an independent measure for the other to establish meanings that we would otherwise have no access to.

As an investigation of courtyards from many periods, the research for this article draws upon twin methodologies which have to an extent been synthesized already, albeit in different ways and for other purposes. A good example is the work of Philip Plowright et al. (2010) on the nature of walls. The authors note that walls are normally defined in technical or pragmatic terms which are ultimately reductionist, whereas the wall is part of a larger system of thought about the built environment and is affected by underlying metaphysical beliefs held by a society'. Tracing the dualism or the discourse of opposites - which in essence is 'inside and out' - the authors seek a philosophical basis for describing the wall, rather than defining it as an institution of opposites. This quest draws them into a multidisciplinary argument that identifies 'the idea of association and assembly' as anti-essentialist.

In the case of the courtyard, the concept of enclosure is more convoluted, because the binary of in and out (as with a wall) is intrinsically challenged. In a courtyard, you are both in, in the sense of enclosed within, and outside in the sense of open to the sky. The investigation demands a slightly different search of lineages, with a stronger invitation to find a rapprochement between the physical language of architecture and spoken language. How were courtyards spoken about and when? How do the terms reveal consciousness of the phenomenon from one epoch to another? If the language changes, does the consciousness change, and indeed does the physical phenomenon change as well? We can only provide the answers where the data can be triangulated, which is the prime method that this article puts to the test.

\section{The place and function of the courtyard}

It is difficult to describe a golden age of the courtyard, even in European architecture. An inner quadrangle surrounded on all sides by a tall house is a mainstay of architecture over several centuries on both sides of the renaissance. Courtyards have their roots in Graeco-Roman antiquity and also the ancient traditions of the Middle East (Edwards et al. 2005) and Asia (Blaser 1979 and 1985). From monastic buildings of the middle ages, with their graceful colonnades surrounding an inner quarter (Dixon \& Lott, 1993), to grand quadrangles such as those of the Louvre in Paris or Somerset House in London, the courtyard is both a practical design and also an aesthetic institution that mutates and reflects the character of the age.

Courtyards largely turn their back on the outside world, which lends all courtyards a peaceful and protected air; they often suggest intimacy and conversation and share a brightly echoing acoustic (Ettouney \& Fricke, 1973; Oldham \& Mohsen, 1979) in which anyone arriving is somehow heralded by the amplified clipclop of feet or horse shoes (Matteo Bandello, Novelle 2.11). But courtyards also communicate qualities specific to a period, from the piety and collectedness of dolce stil novo to the humanism and rationality of the renaissance (like the Palazzo Ducale in Urbino), from the theatrical luxury and sensual pomp of the baroque (like Somerset House in London) to the tall, shared backyard of nineteenth-century tenements for the proletariat.

The age of the courtyard persisted well into the industrial period, where it was integral to large-scale domestic architecture across all levels of society, from working-class housing to spacious apartments for the upper classes in centres like Paris and New York. Following renaissance exemplars, building stock in these dense metropoles occupied the entire block, without gullies or gutters between the façades. Light and air enter both through the façade and (very often) an inner courtyard. Sometimes, the courtyard would be shared between properties, as when two $U$-shaped ground plans meet at the back (like a pair of magnets connecting), granting a courtyard with the virtues of twice the space and light as each property would have afforded by itself.

The urban formula of a building that occupies the whole block without setbacks but with an internal courtyard for light and air is efficient. The plot ratios are much higher than if the periphery of the block were sacrificed for equivalent benefits. One can draw a block of land as a gridded table and count the cells respectively for a setback building or pavilion placed in the middle of the block with peripheral open space and a building occupying the whole block but with an internal courtyard equivalent in width to two side gardens, thus:

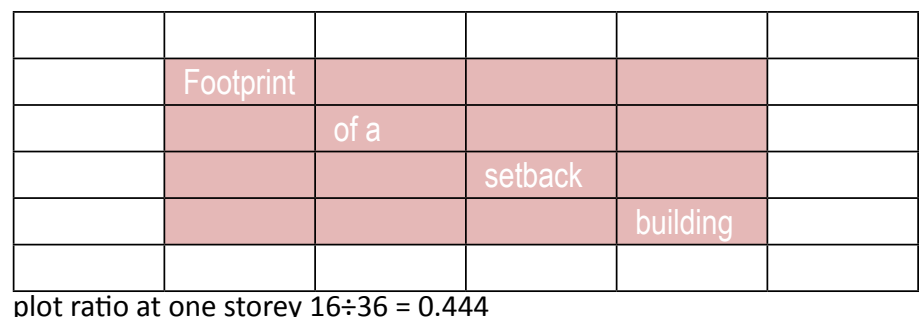

Figure 1: Setback building (pavilion ground plan) 


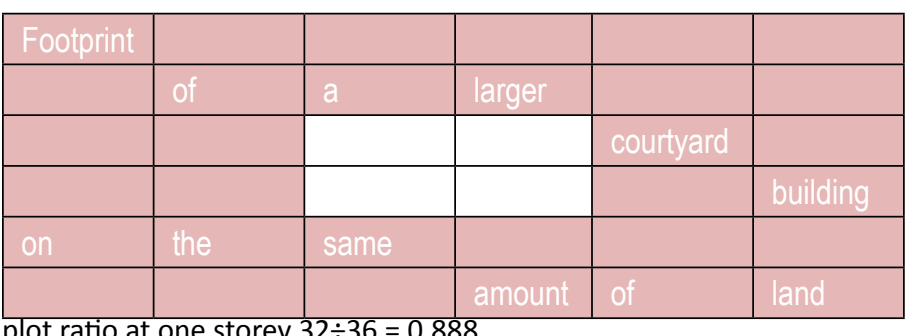

plot ratio at one storey $32 \div 36=0.888$

Figure 2: Courtyard building (wall or street architecture)

The courtyard building has twice the plot ratio of the setback building or pavilion; and this difference is multiplied by each successive storey that one adds. Of course there are circumstances where the block is very narrow, in which case neither arrangement works particularly well; and other contingencies, like stairs or sloping land, all demand consideration. In general, however, one can accommodate twice the number of families in the courtyard building as the setback building. The design therefore has substantial benefits of sustainability, as greater density lessens automotive dependence and creates efficiencies of access to services, before we even contemplate the direct energy benefits of courtyards (Aldawoud \& Clark, 2008; Heidari, 2000; Muhaisen \& Gadi, 2006).

\section{The other side of the street}

This greater density gives a cue to the whole phenomenology of courtyard architecture, which is socialized and paradoxically street-oriented. In the schematic drawings above, the setback design has only a slim margin of land available for garden, which is mostly good for nothing. No one would ever meet there or feel the embrace of the architecture. Meanwhile, the courtyard design presents an internal piazza, a meeting-place, a secluded commons, a sequestered haven; and, unlike the withdrawal from the street in the setback building, the external façades may have a direct bearing upon the street, as in Florence or Barcelona or inner Chicago, which are highly engaged with the community of the street that the building fronts onto.

True to the genius of the street-facing façade, the courtyard then offers a sequence of internal façades that are in conversation with one another. It is an outdoor architecture for the inside, where the building addresses itself rather than talking to the architecture opposite (or 'responding' to the street, as the fifteenth-century author Bandello puts it, Novelle 1.25, 2.22, 2.28, 3.6) or talking to a garden that absorbs the prospect indefinitely or as far as it goes toward a fence. The courtyard contains all its conversations: the four walls talk to one another and make the quietest outside part of the house the most architecturally garrulous. The exterior gains an expressive presence by rising with spectators at close quarters; but it also has the advantages of an interior, with a tranquillity seldom experienced by any façade at the front of a building.
Given the many economic and social advantages, combined with the prolific and august exemplars in the most prestigious centres of architecture, culture and commerce, one might ask why courtyards are used so seldom today; though this question lies somewhat beyond the scope of the present study. To be sure, there are modern courtyard houses (Macintosh, 1973) but courtyards are less in evidence in the automotive age than in premodern times. However, the word 'courtyard' has retained much prestige and is used liberally to apply to suburban circumstances that have negligible architectonic containment: the term turns up to describe almost any little garden or patio at the back of a house, where the area is enclosed by a fence on three sides and the rear of the dwelling on only one side. They are not a courtyard in the sense of a well in the middle of a building which brings light and air into the core of an otherwise solid form. The house has a continuous roof, which covers a series of uninterrupted rooms which terminate in a garden. If we could control language, we might agree simply to call such spaces a garden (even when paved) and to restrict the word courtyard to internal open-air spaces; but no one has the power to ordain the definition of such terms, and the word courtyard is sometimes even preferred when the space is modest and the real-estate agent feels that the word 'garden' might be considered overstatement. The term 'courtyard garden' - meaning a tiny garden - is also not uncommon, with 366,000 instances discovered by Google.

Courtyards are rarer in English-speaking countries than in continental Europe, perhaps because the northern preference for a private block with a free-standing house discouraged the more communal motif of a courtyard, which is ideal for tenements. Victorian architecture in Britain and Australia favours terrace houses with party walls which front onto the street, often with a front and rear garden, both separated from the neighbours by means of a fence. This separation by a free-standing barrier is the genius of the suburbia that followed, whose development was so greatly assisted by cars in the twentieth century. With few exceptions, it is possible to reconcile the pavilion and courtyard: in certain luxurious, leafy and land-rich areas, such as the suburbs of Los Angeles or the Melbourne of Robin Boyd, for example, space could be dedicated to a peripheral garden as well as an internal enclosure (Polyzoides et al. 1). However the efficiencies are poor, and the courtyard in domestic circumstances was doomed during the automotive age.

\section{The lexical weakness of the courtyard}

It is surprising that consciousness of courtyards in Englishspeaking countries is so poor when our language distinguishes itself by having a uniquely pictorial expression for the concept. Alone in the common languages of Europe, our word courtyard contains the two necessary terms, yard and court. The yard is etymologically cognate with garden, which we can still tell by expressions such as 'front yard' and 'back yard'. The term court, on the other hand, has mostly indoor connotations, as in law court, or the court of the Tudors, meaning a kind of tribunal 
chamber where weighty matters of state or rights are determined. In its 'courtyard', English uniquely combines these two images to provide a vivid lexical expression for the architectural reality that we recognize: a space that magically reconciles indoors and outdoors, a kind of hall that is exposed to the elements from above but is protected from all sides by internal façades, analogous in some way to the façades on the street.

We might have a very good word with its two excellent terms in its derivation; it is just that we do not always know what it means. As noted with the usage by real-estate agents that Google discovers, a courtyard can mean a garden at the rear of a dwelling which is faced by three fences. So courtyard has an impeccable derivation but an insecure definition. The weak definition of a courtyard matches its tenuous grip on history, flourishing in pre-automotive periods but little understood or cultivated ever since, in spite of their conversational character, their collectedness, their air of sanctuary and peace. But it turns out that the definition of a courtyard was always vague and illseparated from any fenced enclosure or garden at the back of a property. Even in the eighteenth century, where courtyards were celebrated in theatre, the playwright Carlo Goldoni sets his scenes in the first act of /I conte Caramella in a closed courtyard (cortile chiuso, 1.1-8) with a door in perspective. If he says 'closed courtyard' to describe what we mean by an internal courtyard, it suggests that perhaps the word on its own (cortile) might have meant any yard which is not necessarily closed (and therefore internal) but a garden that goes on till it meets a barrier.

Most of the languages in countries with the best traditions of courtyard architecture lack a unique term for the architectural motif, most notably French - whose court means both an internal room or institution and a courtyard - and German, whose Hof carries the same ambiguity. As noted, Italian has a beautiful term (cortile), which adds an abstracting particle (-ile) to the word for court (corte) to distinguish the courtyard as outdoor architecture from the institution or indoor hall. Similarly, in Spanish one can express the idea of a courtyard (patio; cf. pátio and aido in Portuguese) as distinct from the court (corte), where - especially in the extended terms patio real or patio de rey - the connotations of the king are figuratively carried from the indoor institution to the outdoor space. The physicality of the English combination court-yard also has a distant echo in the Russian term (двор-колодец) which is literally a yard-well, meaning a kind of yard that one might conceive of as a shaft between buildings, like a mine shaft or well, a little like our term for light-well or stairwell or lift-well. The image is built around a technical or functional element of the design, perhaps reflecting an industrial interpretation of the architectural motif.

Today, a yard sounds prosaic, as with backyard, and perhaps working class, as with a cattleyard or railyard. But it can also be regal, as when Shakespeare stages one of his scenes in 'the palace yard' (Henry VIII 5.4) which is presumably a courtyard or something very like. Further, the term is etymologically related to the garden, the garth, the enclosure, and somewhat parallel to court itself, whose Latin origin (cohors) would typically mean a band of soldiers or brigade but also a yard, perhaps because troops in a regiment assemble in a quadrangle outside the barracks. There are echoes of this military context in Shakespeare's references to a tilt-yard, meaning a large strip or ring in which knights on horse charge at one another with lances (2 King Henry IV 2.3 and 2 King Henry VI 1.3).

\section{The experience of courtyards in antiquity}

Our search for the courtyard in language might begin in ancient Greece, where archaeological evidence indicates that courtyards were formidable, as in the famous Stoa of Athens. But the paradox in the way that language handles this august architectural motif already begins in Greek, where the key term ( $\alpha u \lambda \eta \dot{)}$ is both illustrious and common, simultaneously suggesting things lofty and lowly. The word means open court, sure enough; but this place could be before the house, not necessarily a courtyard within it (Iliad 4.433, 11.774, SIG1044.17, an inscription from Halicarnasus from the fourth or third century $\mathrm{BC})$. More disappointingly, the word can also designate a yard or a steading for cattle (Iliad 5.138; Odyssey 14.5). Classical usage indeed suggests a courtyard or quadrangle around which the house was configured (Herodotos 3.77; Aristophanes, Wasps 131; Plato, Protagoras 311a); but it could also be a court in the sense of an indoor hall throughout antiquity, for which the authoritative lexicon LSJ gives many examples. For every grand and lofty case of a court of a temple - as at Inscriptiones graecae 22.1299.28 (third century BC) and 1126.35 - another can be found where the word means any dwelling, abode or even chamber (Sophocles, Antigone 946); further, given that it can be used of a cave (Sophocles, Philoctetes 153; Antigone 786), it is hard to determine where metaphor ends and physical realities begin.

The Greek term also refers to court and courtiers and is clearly the same word as that describing a hall ( $\alpha u \lambda \alpha)$ or court, from which there are verbs ( $\alpha \cup \lambda i \zeta o \mu \alpha \iota)$ and adjectives ( $\alpha u \lambda$ เкós) and even nouns ( $\alpha$ ùoupós) to describe things of the court, courtierlike, courteous - a telling word - and gentle. There were ways to predicate the root using prepositions, such as round-court ( $\pi \varepsilon \rho i \alpha u \lambda \circ v$ ) but this word for courtyard or enclosure is rare and has only been traced to inscriptions from the second and third centuries $A D(L S J S V$.). So too, there is a centre-court or middle court ( $\mu \varepsilon \dot{\sigma} \sigma u \lambda \circ \varsigma)$, perhaps an inner court, inside the palace, also with the variant spelling ( $\mu \varepsilon \dot{\sigma \sigma \alpha u \lambda o \varsigma) . ~ B u t ~ t h o u g h ~ p r o m i s i n g, ~}$ these words could also mean farmyard or the inner yard where cattle were put at night (Iliad 11.548, 17.112, 657, 24.29); and in the Odyssey, the word describes the cave of the Cyclops (10.435).

Language leaves us terms that are sometimes hard to visualize,

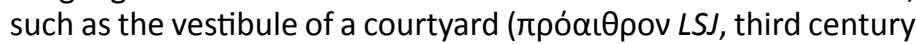
AD) or a passage between two courts of a house ( $\alpha v \delta \rho \omega v i \tau \tau(\zeta)$. The

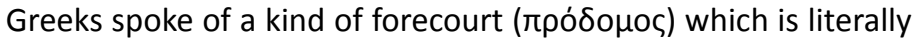


before the house, perhaps something like a front yard. Language also deceives our high expectations, as with the lofty stoa, a word that means the roofed colonnade or cloister where philosphers (hence the stoics) might argue (Herodotus 3.52; Thucydides 4.90, 8.90; Xenophon, Hellenica 5.2.29, 7.4.31; and the biblical John 10.23) but it could also designate a storehouse or a magazine for corn (Aristophanes, Acharnians 548); and if one wanted to indicate a portico with a function more august than that of a shed, one had to predicate the term with 'royal' or 'kingly' (Plato, Theaetetus 210d), a bit like the pattern noted earlier in Spanish.

\section{The experience of courtyards in the renaissance}

Given that Greek already related court and courtyard, it would suit the romance of my case to exploit this compelling metaphor and to celebrate the link between the architectural courtyard and the courtly, to enjoin linguistic history to induce courtesy and courtship upon the space. So much in the history of ideas argues for the development of culture around the courtly, as in Boccaccio's description of a worthy man of the court who is cultured and well-spoken ('valente uomo di corte e costumato e ben parlante', Decameron 1.8). By extension, the courtyard could thence become the natural site for the beautiful frolicking of courtiers that one might entertain in one's fantasy. Alas, the overlap between these words is more a sign of the weakness of language, or rather the organically concatenating quality of linguistic development, which we easily trace to ancient Greece. An incipient tendency to confine the court to the indoors can already be seen in the Greek language. The Greeks tellingly span the word for curtains ( $\alpha u \lambda \alpha i \alpha)$ out of the word for court ( $\alpha u \lambda$ n) because curtains belong to the sumptuous accoutrements of a regal hall, trappings which do not belong outdoors. So too, the word 'curtain' (derived from a diminutive of court, cortina) also comes from court according to the prestigious Greek formula. This translation of image rather than roots of words reinforces the deep pertinence of the court to the interior environment (Zako, 2005). The court is a place of curtains.

When we encounter courtyards in modern language, they are projected as charming almost to a boastful degree. The beginning of Boccaccio's beautiful Decameron contains a description of a palace on a little mountain to which the aristocratic company (brigata) repairs from the plague-stricken metropolis. 'Sequestered somewhat from our streets' (lontano alquanto alle nostre strade) in a way that predicts suburban aspirations, this aristocratic house has a 'beautiful and large courtyard in the middle' (bello e gran cortile nel mezzo) with loggias and rooms, all turned out beautifully 'in joyfully ornate and admirable paintings', surrounded by lawns (pratelli) and 'marvellous gardens and ponds with the freshest water' (Boccaccio, Decameron 1.0 introduction).

Far from our concept of a townhouse, the villa is on the outskirts - as if a cue for Los Angeles - where the rooms look out upon the surrounding grounds as well as the courtyard within. The courtyard might therefore be a condiment to the variety of spaces and moods rather than a necessity for light and air or access. One might think of several renaissance paintings in which holy narratives are staged in a courtyard which gives onto a distant garden (as in Piero della Francesca's Annunciation from the Polyptych of St Anthony, Galleria Nazionale dell'Umbria from the fifteenth century). The courtyard is well represented in renaissance iconography, even in weighty scenes like the Last Supper or dramatic scenes, like Donatello's Banquet of Herod in the Siena Cathedral Baptistery, where painters and sculptors could exercise their sense of the ideal as much as Boccaccio did in his image of the perfect country estate with the courtyard in the middle.

Artists did not merely depict courtyards. They worked in and upon them. In Vasari's compendious Lives of the Painters, courtyards are often mentioned as a site of important production. Thus, we read about figured and ornate projects in the Life of Giotto, including the doors, twice in the Life of Donatello, the architect Michelozzo, Alesso Baldovinetti, Fra Filippo Lippi, Antonio Rossellino (concerning the marble fountain in the courtyard of the Palazzo Medici), Cosimo Rosselli (frescos in the colonnade), Perugino (with a frieze above the columns) and Raphael. A courtyard project is mentioned several times with Andrea del Sarto and Francia Bigio, twice with Dosso, once with Rosso Fiorentino and Girolamo da Trevigi, twice with Polidoro da Caravaggio and Maturino Fiorentino, twice with Antonio da San Gallo and twice with Giulio Romano, artists who have since been more identified with architecture. Vasari's own introduction to architecture contains three references to courtyards.

A courtyard is not a cloister, which indicates enclosure lexically but which was overwritten with monastic purposes right into the baroque (La Rochefoucault, Maximes fournies par des témoignages de contemporains 19; La Bruyère, Les caractères 7.36 and 12.7) and whose contemplative sanctuary must have been essential to spiritual withdrawal. By contrast, a courtyard in most circumstances is tied to household activity.

However, the courtyard was also civilized and did not have to accommodate horses or stables. Thus we read in Bandello's huge collection of novelle of a Neapolitan house which was very large, with a beautiful courtyard, windows and superstructure. The stables were kept 'far enough away from the house' (assai discoste da la casa, Bandello 1.5); though it appears that one dismounted in the courtyard of the Palazzo del Contestabile (2.34) which suggests that the horses entered the space, even if they were then taken away to stables elsewhere. In another story again, a gentlewoman is going about her business in the courtyard (andata nel cortile a far certe sue bisogne) and is delighted to spy a stable-hand plying his penis with fat in order to procure an outcome that she satisfies more expediently with her vagina (2.59).

The density of Italian towns in the renaissance, like now, meant 
that you were never very far from someone else's courtyard. For example, a helpless paramour is discovered by an armed husband who, however, is clement: he orders him to get out by a window and, in so doing, the lover jumps into the neighbour's courtyard (saltò giú in un cortile d'un vicino, 1.11). It sounds more like a backyard - 'a garden circummur'd with brick', as Shakespeare says (Measure for Measure 4.1) - how would you jump from your building into someone else's courtyard if all courtyards were internal? Or perhaps the window opened onto the neighbour's courtyard because the building next-door attached to your long wall in a $U$ shape.

The courtyard is intimate but also public. Thus, for example, dead bodies could be displayed there for the public to view with funereal pomp (1.44) and, in another story, we read of an architectural modification of a particularly busy house in order to prevent people entering the courtyard (1.53).

It would be wrong to think that just because courtyards became such a mainstay of domestic design - extrapolated by the institution of the town square and palatial courts - that a definition arose as solid as our architectural image of their design and purpose. Still in Bandello, one hears of a courtyard with a hedge (2.1). It is not as if it is a low box hedge planted within the courtyard in a formal garden design: the hedge must actually constitute the wall, because a protagonist cuts a hole in it and thus gets out of the courtyard and heads toward the stables. So it is hardly a courtyard by our preferred definition.

In a story which celebrates the sexual exploitation of a credulous young woman (2.1), a courtyard with a fountain is closed by means of a gate (uscio). In the action, which describes a rape by deception, we discover that as well as the fountain from which the lass takes water with two buckets, there is hay in the courtyard for a donkey which the lord keeps in his house for his needs. It sounds more like a farmyard than an urbane architectural environment. Although it might have been usual to have horses domiciled in internal stables off the courtyard in a townhouse, as already noted, horses entered the courtyard and brought people to the internal doors. The report of horses' hooves is noted in a number of stories (2.11) for which there are rustic echoes still in the eighteenth century in the plays of Carlo Goldoni. In I/ conte Caramella, for example, the playwright calls for a 'closed courtyard with a door in perspective', through which the harvesters pass, as well as a farm gate (porta rustica, 1.1-8). The same play calls for a ground-floor room which answers the courtyard (sala terrena corrispondente al cortile, 3) of which Goldoni seems to have been proud, since he notes that the above scenes belong to the beautiful architecture of Signor Francesco Zanchi. The abundance of courtyards in Goldoni's theatre ( $L a$ diavolessa 2.1-13; La contessina 1.3-9 and 2.3-10) requires discussion in its correct historical sequence.

In the sixteenth century, courtyards sometimes had a narrow staircase in them (scaletta) which facilitated both escape and
- because access to them could be controlled - confinement (Bandello 2.11) in the event of family brawls, which were not without comic value. One way to get your jealous husband to jump from a window onto the street was to light a fire in the courtyard (2.25) so that he would fear the whole house would engulf him in flames, where in fact the conflagration was contained and carefully fuelled by the straw from the mattresses that needed to be refilled. We also hear of someone jumping into the courtyard from a high window and breaking bones (2.38).

The courtyard, of course, also represents the bottom of a building (a basso). For that reason, it can be related to work and the provision of services to the house (alcuni servigi 2.41), a literally lowly motif that survives into the eighteenth century ('giù nel cortile', Goldoni, L'osteria della posta 1.8; cf. La cascina 2). But from the renaissance, it can also be used for leisure and coolness in the great heat of summer, where, in one story, a wife seeks refuge and is erotically surprised by her lusty husband (Bandello 2.52). The courtyard was not just for nobility or merchants but also the poor (in un cortile sedeva, ove molte famiglie di poveri uomini albergavano, 2.58). The courtyard had many functions and could contain a well, deep enough to be drowned in (Bandello 3.33).

The idea of a courtyard being a kind of garden or even an inhospitable pit is suggested by one story in which lions are kept there (Bandello 3.39). In a letter by Bandello introducing another story, we even hear of an ape in festive clothing being leashed in a courtyard (3.64).

\section{The courtyard as European stage}

As tourists in continental Europe, we tend to experience grand courtyards of the urban nobility. They are often illustrious, with lavish ornament, a place of marvel because of their figuration. Almost as if they had outgrown their humble origins, courtyards in seventeenth-century verse tend to align with fantasy rather than fact. In Shakespeare, for example, there are no courtyard scenes named as such. With the exception of one scene which calls for 'an Inn-Yard' (1 Henry IV 2.1) and the tilt-yard already noted, the corpus has nothing but rooms, streets, battlements, beaches and fields. So too in France, where, for instance, the tragedian Racine never calls for a courtyard, unless we interpret the scene of his Bérénice as a courtyard by another name: 'the scene is in Rome, in a hall [cabinet] which is between the apartment of Titus and that of Bérénice'. It occupies the theatrical position that in the eighteenth century would be named a courtyard, as in Goldoni's play stipulating the architectural and dramatic liaison between two apartments in Lugrezia romana in Costantinopoli (1.6).

The theatrical commodity of courtyards is not just that a courtyard bears a physical resemblance to a theatre - a closed platform or scene on a pit surrounded by structures that look onto it there are also metaphoric reasons. The courtyard has a function which is both neutral and nodal: it liaises between rooms and 
therefore people with their separate business. If you watched a courtyard from the first floor, you would notice people going onand off-stage, always with a slightly fresh purpose. As noted, the building which necessarily has a façade on the street figuratively 'begins again' on the inside, where another set of façades flank the rooms inside the building. Just as in a play, where a new act begins life again, the courtyard symbolizes another backdrop which is not the primary reality of the street.

When lyrical poets in seventeenth-century Italy, say, describe courtyards, they are otherworldly, imaginary pieces of verbal invention, as in Marino, where metaphors spill out of architecture and fountains (L'Adone 3.164-66, 5.112-13) with the kind of symmetry that you would expect in a theatrical backdrop and which would later be exploited on the stage, as in the royal palace of Xerxes in Goldoni's Aristide (1.1-8). The courtyard could also be used as a metaphor for heaven, like a divine airborne chamber whose very element is celestial light (L'Adone 10.120).

Poets have inscrutable reasons to visit this scene or that and caution should be exercised before great significance is attributed to a lack or abundance of courtyards in this epoch or that. For example, the seventeenth century yielded relatively few street scenes in French and Italian painting, but that does not imply that these cultures had a weak consciousness of streets; on the contrary, the architectural and literary evidence is superabundant in the cities of France and Italy that street life was lively and colourful (Nelson 2014). Historical evidence only tells us about the past when it is present, not when it is absent. But when we do find rich iconography around streets, we have much insight into the urban circumstance.

Courtyards feature often on the European stage in the eighteenth century. Easy and satisfying to render upon the scenic backdrops of the theatre, the courtyards acted in perfect accord with the concentration of sound and attention in the theatre itself. The theatre, after all, is an indoor space that figures the outdoors; and because the courtyard is both an internal space and an open-air environment, it answers as if by magic the structural suggestiveness of the theatre. Thus, when the Venetian playwright Carlo Goldoni creates a play about the theatre in II teatro comico, he describes the single set (scena stabile) as the theatre itself (il teatro medesimo) in which comedies are presented, with scenes and the prospect of a courtyard.

In the large corpus of comedies by this ingenious author, we find ourselves witness to scores of courtyards, courtyards where we not only witness activities within, like dancing to the sound of a guitar (L'Apatista 4.9), but where figures even make reflective comments on their design (Oibò, questo cortile / $̇ ̀$ male architettato) which occurs in a play (II viaggiatore ridicolo 1.9) with multiple scene changes, of which three have a courtyard. From the many examples, we get a sense that life was free and easy in the courtyard, suitable indeed for comedy, as when a patron's servants drink there and indulge in gaming (II ricco insidiato 5.6).

Goldoni's plays are full of set-changes (mutazioni di scene) where courtyards are sandwiched between other scenes, as in the first act of II paese della Cuccagna, which features a beach with shipwreck, a farm scene, and a 'courtyard in the viceregal palace of Cuccagna'. So too in I bagni di Abano, the first act begins with a courtyard that fronts onto the baths (cortile corrispondente ai Bagni) as well as a room of the communal house and a dance scene. A courtyard is described in the second act of Le virtuose ridicole, where the first was a 'delicious garden' and the remaining scenes are an apartment and a 'magnificent salon'. The third act reverts to a courtyard, but not for long. Once again, these scenes are described as belonging to the 'gorgeous designs' (vaga architettura) of Signore Francesco Zanchi.

Sometimes the description of the courtyard is telling. One scene of L'uomo prudente (2.18) is described as a courtyard in the house of Pantalone while another is a 'courtyard with two gates or perhaps shops' (or stores, 'Cortile con due porte terrene, o sian magazzini', 3.13). The idea that the courtyard would front onto garages or stores indicates the workaday character of the space. Even a pharmacist has a courtyard, which might equate with the counter (Lo speziale 3.1). As in Bandello two centuries before, it all depends on the level of society. In bourgeois circumstances, decorum is expected. When Silvio wants to make a fuss in the courtyard at the house of Pantalone, the sage Dottore discourages him, exhorting him to leave the courtyard and not make a scene ('esci di questo cortile, non facciamo scene', Il servitore di due padroni 2.1).

As in the renaissance, it is sometimes hard to picture what a courtyard looks like. For example, if the courtyard in the house of Momolo looks to the Brenta (II prodigo 1.1-1.8), what does that mean? Is there a kind of proscenium or door that gives onto the view; or is the whole space more like a yard? The more picturesque Goldoni insists a courtyard is, the harder it is to envisage, as in I portentosi effetti della madre natura, which involves an ancient courtyard with a fountain, aqueduct and arches from which one passes to the Palazzo di Ruggiero (2.4). Exactly where these large structures would fit is hard to imagine; though the third act calls more understandably for a courtyard festively adorned with triumphal arches. Likewise, in Le pescatrici, the picturesque set changes include lush enclosures of shady trees in the first act, while the second act opens with a courtyard that gives onto a 'delectable garden' (Cortile che introduce al giardino delizioso, 2.1). The same term is used of the garden in the house of Ecclitico (II mondo della luna 2) which has a drawbridge that 'unites the garden with the courtyard', as if the courtyard is hemmed, on at least one edge, by a moat.

In Goldoni's theatre, the grandeur of courtyards is as important as their intimacy. The playwright calls for a 'spacious courtyard' terminating in 'majestic arches' beyond which one sees the large piazza (II mondo alla roversa 1). Like a courtyard, a piazza is not 
necessarily grand. For example, in II mercato di Malmantile, the market square has various shops and benches for sellers in the first act; and whereas the second and third acts take advantage of the peace of the courtyard, they are more intimate than grand. We are reminded that the man who is now the governor was also born in lowly condition in a courtyard (Nato è anch'egli villan nel mio cortile, 2.10). You can expect a courtyard at an inn (La mascherata 2) and for the courtyard to accommodate the benches used for toping (L'amore artigiano 2.15-17).

Even if the courtyard represents authority, it does not necessarily entail a happy disposition, as in the courtyard of the Place of Justice with stake, stage and fire and various ministers of execution' (Il genio buono e il genio cattivo 4.9) with a narrow stair by which a tower connects with the courtyard. Similarly, Pietro Metastasio takes us into the 'internal courtyard of the gaol in which Timante is kept' (Demofoonte 3.1; cf. courtyards in his Siroe 3.1, Catone in Utica 3.1 and Adriano in Siria 1.12).

One can also, though rarely, do business in a courtyard, as in an ancient palace of the Marquises, where a table and chairs attend and the chancellor declares it an ideal place to confer the deeds: 'in this courtyard, we will do everything' (II feudatario 2.15-17). But the assumption in this vignette is that you would not necessarily expect to do great business in a courtyard. Like a garden, a courtyard is a place where you can wait without feeling idle; the space is not devised for rhapsodic seduction but gathering. It is a place for pause or pacing oneself for an opportunity: 'I will move into the courtyard and will wait for the most favourable moment' (Goldoni, La castalda 2.8).

\section{The courtyard goes off-stage}

Sequestered and safe, this architectonic asylum is nevertheless utterly social. Courtyards are qualitatively different from gardens, even though nothing prevents a courtyard accommodating a garden or having elements of a garden in its design. Even so, the courtyard will create a garden quite different in character to a peripheral one, that is, a garden surrounding the outer walls of a free-standing building, and which therefore faces onto either a street or a fence as well as the building.

The reasons for the relative demise of the courtyard are both technological and conceptual. This article is more concerned with what courtyards are and how their gestation and history are reflected in language; and explaining the demise of the courtyard lies somewhat beyond its scope. However, for further study, one might conjecture a number of reasons which are helpful for clinching the insights that we might have obtained from reading the pre-industrial evocations of their design and function. In the large city towers of today, there is often no place for a courtyard, because the internal space is used for vertical transport, especially at the lower levels where the shafts are wider, thanks to elevators that terminate at medium heights. In mediumheight buildings (let us say 4-7 storeys), there was a temptation from the post-war period onward to fill in the entire piece of land with accommodation, perhaps thanks to cheap neon lighting, which meant that internal spaces could be lit without requiring natural light to filter in through a courtyard. And in contemporary complexes for accommodation and business, a courtyard would seem difficult to reconcile with the plunging driveway for underground carparking.

In suburban circumstances, as noted, there is also often no space. By local legislation or suburban convention, apartments and houses are often configured around mandatory setbacks, so that a percentage of the land must be set aside for gardens and driveways. As well as shrinking the footprint of the building and leaving too little space for a courtyard, the peripheral garden aspect makes the internal space redundant for lighting.

It is a pity, especially because the standard quarter-acre block that characterizes so many subdivisions in America and Australia has workable proportions for apartments with a central courtyard; in fact the quarter acre upon which a solitary bungalow is placed in the new world would have been considered generous in Mediterranean countries that have multi-storey buildings configured around courtyards. Alas, the garden ethos of the suburbs is always likely to prevent the development of housing that reaches to the fence and opens up the scope for efficient internal spaces.

In Australia, that most suburban of countries, a beautiful article by Julie Szego appeared in a newspaper (2012) which richly documented the communal life of a courtyard environment in her block. The article carried an editorial image showing a prolific garden, watered by a solitary man brandishing a hose. Tellingly, this image contained none of the virtues that the author expressed. Instead, the figured courtyard could have been a backyard anywhere. It gave no indication of any qualities peculiar to courtyards.

Unrecognized, suppressed by regulations, technically superseded by electrical lighting and air-conditioning or squeezed out by the need for large lift-shafts or underground carparks, the courtyard is unconsciously regarded as a luxurious feature, perhaps a gratuitous mannerism, a waste of an internal room, especially when the building is already surrounded by garden. To add insult to injury, as we have discovered, there is little common agreement as to what an internal courtyard is, despite the very many aesthetic pilgrims who visit the gorgeous spaces in Europe that are conspicuously configured around that lively void, that gap in the dense built environment where the architecture talks to itself. One visits and marvels and then forgets.

As well as the old building stock which tells its own story so eloquently, we have a lexical history and a literary record that reveal how the experience of courtyards has always struggled for adequate language. Visually brilliant and symbolically unforgettable in reconciling grandeur and cosiness, the courtyard 
is nevertheless remarkably fugitive in consciousness, where even in some of our most sophisticated languages, there is no dedicated word to describe it.

Small wonder, then, that when architecture confronts modern circumstances, the courtyard all but perishes, especially in the English heritage of insular low-rise nineteenth-century terrace houses, based upon front and back gardens. And finally, green sentiment has urged all open spaces to be interpreted as landscaping rather than pavement, so that the social architectonic space between façades is gardenized out of its former sociable traditions. Fortunately, however, there is more than enough in the record to salvage the motif from the lexical neglect of millennia and the aesthetic neglect of a century, because their virtues are enormous. A creative revaluation would seem in order.

\section{CONCLUSION}

This exposé of the courtyard has attempted to bring together the phenomenological and the philological, proposing a timeline in which courtyards grew as both a mainstream building archetype and an adorable stage for interaction, but without a corresponding lexical stability. The ambiguities of contemporary usage of the word 'courtyard' are not unprecedented; because we have discovered that accuracy and consistency around the concept was never to be found, including in the languages (like English) that have dedicated terms for the phenomenon.

Defining the several architectonic advantages of internal courtyards, this paper has traced the history of the motif through the evidence of building archetypes and lexical and literary records. Despite the literal centrality of courtyards to so many traditions of urban construction, the spatial motif has not survived strongly in contemporary architecture; and it is tempting to relate this weakness to the equivocation of the word. Our generation has to predicate the term with the adjective 'internal' to be quite sure that we understand the term 'courtyard' to mean that remarkable 'void' in the middle of a building.

In the process of recognizing the lexical and phenomenological history of the courtyard, we have unearthed a consistent portrait of social presence in this site, with an engaging dynamism - both intimate and public - which no other part of a building has. The stories accord with the spatiality: it is a theatre of astonishing vivacity which is only made more fascinating by being matched with the many paradoxes of its history in language and form.

Finally, the examination of the courtyard through broad architectural history and philological method suggests that architectural discourse can embrace the subjective or poetic intuitions of the viewer and square them (which is perhaps a nicer word than 'triangulate' for a courtyard) with historical fact. As Philip Plowright has demonstrated (2014), architectural process is littered with conceptions, knowledge domains, domain syntax, coherence, framing and thinking styles. If this is true of the creative process, it is equally true of architectural appreciation. We do not see or experience architecture without simultaneously keying our perception onto conceptions developed in language. These conceptions that play such a large part in conditioning our perceptual awareness are highly historical and have origins from time immemorial in language itself. Armed with this backdrop to the very way that we see and take stock of our architectural surroundings, we might develop a more critical view of architectonic experiences worth recreating in contemporary practice.

\section{REFERENCES}

Numbers to classical and biblical texts follow the standard reference system derived from the canonical editions used in lexicography. Different editions and translations have disparate pagination, whereas the canonical numbering is consistent. Similarly, the numbering used in renaissance and baroque texts follows the order of canto/stanza for epic poems, act/scene for plays or book/story for novelle or essays.

Aldawoud, A., and Clark, R. 'Comparative analysis of energy performance between courtyard and atrium in buildings'. Energy and Buildings: Elsevier 2008

Blaser, W. Courtyard house in China: tradition and present (Hofhaus in China: Tradition und Gegenwart). Birkhäuser: Basel 1979

Blaser, W. Atrium: Five thousand years of open courtyards. Wepf \& Co.: Basel 1985

Dixon, P., and Lott, B. 'The courtyard and the tower: contexts and symbols in the development of late medieval great houses'. Journal of the British Archaeological Association: Maney Publishing 1993

Edwards, B., Sibley, M., Hakmi, M. and Land, P. Courtyard housing: past, present and future. Taylor \& Francis: Abingdon 2005

Ettouney, S., and Fricke, F. 'Courtyard acoustics'. Applied Acoustics: Elsevier 1973

Heidari, S. Thermal comfort in Iranian courtyard housing. University of Sheffield 2000 (dissertation)

Macintosh, D. The modern courtyard house: a history. Lund Humphries for the Architectural Association, London 1973.

Muhaisen, A., and Gadi, M. 'Effect of courtyard proportions on solar heat gain and energy requirement in the temperate climate of Rome'. Building and Environment: Elsevier 2006

Nelson, R., 'The language of the street: a vocabulary of communal 
space', Chora 7, McGill University, Montreal 2014.

Oldham, D., and Mohsen, E. 'A model investigation of the acoustical performance of courtyard houses with respect to noise from road traffic'. Applied Acoustics: Elsevier 1979

Plowright, P. Revealing architectural design: methods, frameworks and tools. Routledge: Abingdon 2014

Plowright, P., Stevens, J. and Adhya, A. 'Enclosure: Lineages', Proceedings of the Conference on Sustainability and the Built Environment. King Saud University, Saudi Arabia. 3-6 January 2010

Polyzoides, S., Sherwood, R. and Tice, J. Courtyard housing in Los Angeles, Princeton Architectural Press: New York 1992

Szego, J. 'A fresh look from our windows'. The Saturday Age 6-7 April 2012. p. 22.

Zako, R. 'The power of the veil: gender inequality in the Domestic setting of traditional courtyard houses'. in Edwards, B., Sibley, M., Hakmi, M. and Land, P. (eds). Courtyard housing: past, present and future. Taylor \& Francis: Abingdon 2005 